\title{
Surfactant Assisted Sonochemical Synthesis and Characterization of Gadolinium Doped Zinc Oxide Nanoparticles
}

\author{
Heena Khajuria, Jigmet Ladol, Rajinder Singh, Sonika Khajuria \\ and Haq N. Sheikh* \\ Post-Graduate Department of Chemistry, University of Jammu, Baba Sahib Ambedkar Road, \\ Jaтmи Tawi, 180006 India \\ * Corresponding author: E-mail: hnsheikh@ rediffmail.com \\ Tel.: +91-191-2493124 Fax: +91-191-2431365
}

Received: 24-03-2015

\begin{abstract}
Pure and Gd doped Zinc Oxide $(\mathrm{ZnO})$ nanoparticles were synthesized by sonochemical method using different surfactants (PVP/CTAB). The nanoparticles were characterized by powder X-ray diffraction (PXRD), Fourier transform infrared spectroscopy (FTIR), scanning electron microscopy (SEM), energy dispersive X-ray spectroscopy (EDS), particle size analysis by DLS technique and UV-Visible spectroscopy. The effect of Gd doping and nature of surfactants on crystallite size, morphology and band gap of $\mathrm{ZnO}$ nanoparticles have been investigated. In addition to this, the effect of nature of surfactant on amount of dopant inserted in the $\mathrm{ZnO}$ lattice was also studied.
\end{abstract}

Keywords: Polyvinylpyrrolidone; cetyltrimethyl ammonium bromide; ultrasonic synthesis

\section{Introduction}

Nanosized semiconductors have attracted extensive interest due to their unique properties and applications. ${ }^{1-3} \mathrm{~A}$ lot of research work has been done in the synthesis and characterization of semiconducting nanostructures such as $\mathrm{ZnO}, \mathrm{ZnS}, \mathrm{PbS}, \mathrm{CdS}, \mathrm{CdSe}$ and $\mathrm{Ti}-$ $\mathrm{O}_{2}{ }^{4-8} \mathrm{ZnO}$ is one of these semiconductor materials which have great potential for applications in photocatalysis, solar cells, chemsensors, transducers, transparent electrodes, electroluminescent devices and ultraviolet laser diodes. The applications of $\mathrm{ZnO}$ are because of its novel properties such as direct wide band gap $(3.37 \mathrm{eV})$, optical transparency and large exciton binding energy $(60 \mathrm{meV})$ that ensures significant excitonic emission at room temperature. In addition, $\mathrm{ZnO}$ is inexpensive and environmental friendly as compared to other metal oxides. The properties and applications of $\mathrm{ZnO}$ can be improved by modulating its bandgap ${ }^{9}$ and controlling its morphology and particle size. ${ }^{10}$ This can be achieved by doping of selective elements into $\mathrm{ZnO}$. Doping induces drastic changes in its optical, electrical and magnetic properties by modifying its electronic structure. ${ }^{11-13}$ Dif- ferent methods have been used for the synthesis of doped $\mathrm{ZnO}$ such as laser ablation, ${ }^{14}$ magneton sputtering, ${ }^{15}$ high temperature calcinations, ${ }^{16}$ sol-gel, ${ }^{17}$ hydrother$\mathrm{mal}^{18}$ and sonochemical methods ${ }^{19}$. Among these techniques, sonochemical method has attracted much attention. ${ }^{20-22}$ It is based on acoustic cavitation resulting from the continuous formation, growth and implosive collapse of bubbles in a liquid. ${ }^{23}$ It has become one of the useful, green, simple and fast methods for the synthesis as well as doping of nanostructures.

Till now, number of studies on various transition ( $\mathrm{Fe}, \mathrm{Co}, \mathrm{Mn}$ etc.) and inner transition metal ions (Er, Nd, $\mathrm{Ce}, \mathrm{La}, \mathrm{Eu}$, etc.)-doped $\mathrm{ZnO}$ have been reported. ${ }^{24-31}$ Lanthanide ions are considered as excellent candidates as dopant of the $\mathrm{ZnO}$ due to their many optical and magnetic advantages. Gd is recognized as a potential dopant and has become the focus of numerous investigations because of its promising applications in optoelectronic and magnetic devices. ${ }^{32}$

Here, we report synthesis of $\mathrm{Gd}$ doped $\mathrm{ZnO}$ with varying dopant concentration $(0.5 \mathrm{~mol} \%, 1.0 \mathrm{~mol} \%, 1.5$ $\mathrm{mol} \%, 2.0 \mathrm{~mol} \%$ ) by sonochemical method. The synthesis of nanoparticles was carried out in the presence of 
surfactants namely polyvinylpyrollidone (PVP) and cetyltrimethyl ammonium bromide (CTAB). Surfactants have the ability to control the morphology ${ }^{33}$ and size distribution of nanoparticles ${ }^{34}$ and it has been found that surfactants also control the concentration of dopant inserted into the host lattice. Hence, the effect of these additives (PVP and CTAB) and that of concentration of dopant $\left(\mathrm{Gd}^{3+}\right)$ on particle size, morphology, and optical properties of $\mathrm{ZnO}$ nanoparticles was investigated by means of different techniques such as XRPD, FT-IR, EDS, SEM and UV-Visible spectroscopy and particle size analysis.

\section{Experimental}

\section{1. Materials}

All reagents used for the synthesis were commercially available and used as received. Zinc acetate and cetyltrimethyl ammonium bromide were purchased from Acros. Polyvinylpyrrolidone was purchased from Sigma Aldrich and gadolinium nitrate was purchased from Alfa Aesar. Doubly distilled water was used to prepare aqueous solutions.

\section{2. Synthesis}

To prepare undoped $\mathrm{ZnO}$ nanoparticles, $50 \mathrm{~mL}$ aqueous solution of $(0.10 \mathrm{M}, 1.09 \mathrm{~g})$ zinc acetate and surfactant PVP/CTAB $(0.5 \mathrm{~g})$ was prepared. The mixture was positioned in a high intensity ultrasound probe and sonicated for $30 \mathrm{~min}$. Aqueous solution of ammonia (5\%) was slowly added in the above sonicated solution. In this step, nano-structured zinc hydroxide was formed.

$$
\begin{aligned}
& \mathrm{Zn}\left(\mathrm{CH}_{3} \mathrm{COO}\right)_{2}(\mathrm{aq})+2 \mathrm{NH}_{4} \mathrm{OH} \rightarrow \\
& \rightarrow \mathrm{Zn}(\mathrm{OH})_{2}(\mathrm{~s})+2 \mathrm{CH}_{3} \mathrm{COONH}_{4}(\mathrm{aq})
\end{aligned}
$$

At the end of process of adding ammonia solution, the mixture was sonicated for $1 \mathrm{~h}$. The precipitated zinc hydroxide was filtered and washed with distilled water and ethanol. The precipitates were dehydrated at $320{ }^{\circ} \mathrm{C}$ for $2 \mathrm{~h}$ in air.

$$
\mathrm{Zn}(\mathrm{OH})_{2}(\mathrm{~s}) \rightarrow \mathrm{ZnO}(\mathrm{s})+\mathrm{H}_{2} \mathrm{O}(\mathrm{g})
$$

During dehydration, nanostructured zinc oxide was formed. The nanoparticles were sonicated in ethanol for $30 \mathrm{~min}$ to eliminate agglomeration, centrifuged and dried at $70{ }^{\circ} \mathrm{C}$ in air. $\mathrm{Gd}^{3+}$ doped zinc oxide were obtained under the similar conditions by replacing a fraction of $\mathrm{Zn}\left(\mathrm{CH}_{3} \mathrm{COO}\right)_{2}$ by $\mathrm{Gd}\left(\mathrm{NO}_{3}\right)_{3}(0.011 \mathrm{~g}),(0.022 \mathrm{~g})$, $(0.034 \mathrm{~g})$ and $(0.045 \mathrm{~g})$ for $0.5 \mathrm{~mol} \%, 1.0 \mathrm{~mol} \%, 1.5$ $\mathrm{mol} \%$, and $2 \mathrm{~mol} \%$ doping respectively). The scheme of the synthetic procedure of $\mathrm{Gd}$ doped $\mathrm{ZnO}$ is presented in the Figure 1.

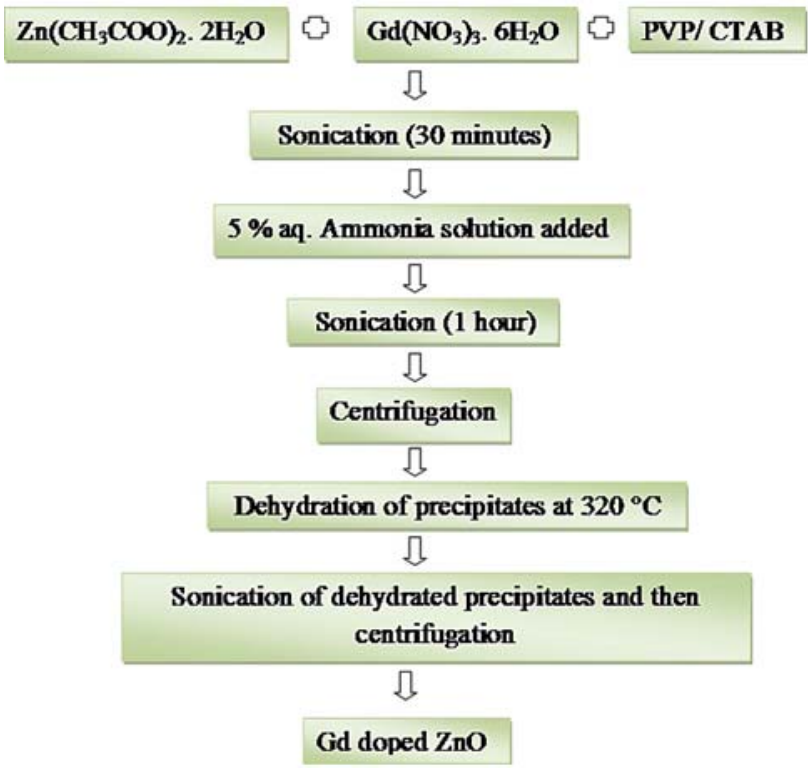

Figure 1. Flowchart of synthetic procedure of Gd doped $\mathrm{ZnO}$.

\section{3. Characterization}

The crystalline phase structure and size of the products were determined from X-ray powder diffraction (XRPD) using Panalytical X'pert-Pro diffractometer system in the $2 \theta$ range from $10^{\circ}$ to $80^{\circ}$ with $\mathrm{Cu} \mathrm{K} \alpha$ radiation $(\lambda=1.5418 \AA)$. The morphology of the as prepared samples was observed using scanning electron microscope (Quanta 200 3D) equipped with EDS measurement. The UV-Visible absorption spectra of the samples were recorded on T90+ UV/Vis Spectrophotometer (PG instruments Ltd). The FT-IR spectra of the prepared samples were recorded by using Shimadzu Prestige-21 infra-red spectrophotometer. The particle size of the samples was determined by the dynamic light scattering (DLS) technique using a Zetasizer nano ZS 90, Malvern make. All the measurements were performed at room temperature.

\section{Results and Discussion}

\section{1. Infrared Spectroscopy}

FT-IR spectra of prepared undoped and Gd doped $\mathrm{ZnO}$ nanoparticles were recorded in the range of

Table 1. IR frequency shift of $\mathrm{Zn}-\mathrm{O}$ stretching frequency under the influence of Gd doping.

\begin{tabular}{llc}
\hline Sample & PVP & CTAB \\
\hline Undoped $\mathrm{ZnO}$ & \multicolumn{2}{c}{$\boldsymbol{v ( Z n - O ) ~ / \mathbf { c m } ^ { - \mathbf { 1 } }}$} \\
0.5 mol\% Gd: $\mathrm{ZnO}$ & 480 & 482 \\
1.0 mol\% Gd: $\mathrm{ZnO}$ & 455 & 474 \\
1.5 mol\% Gd: ZnO & 449 & 447 \\
2.0 mol\% Gd: ZnO & 446 & 435 \\
\hline
\end{tabular}




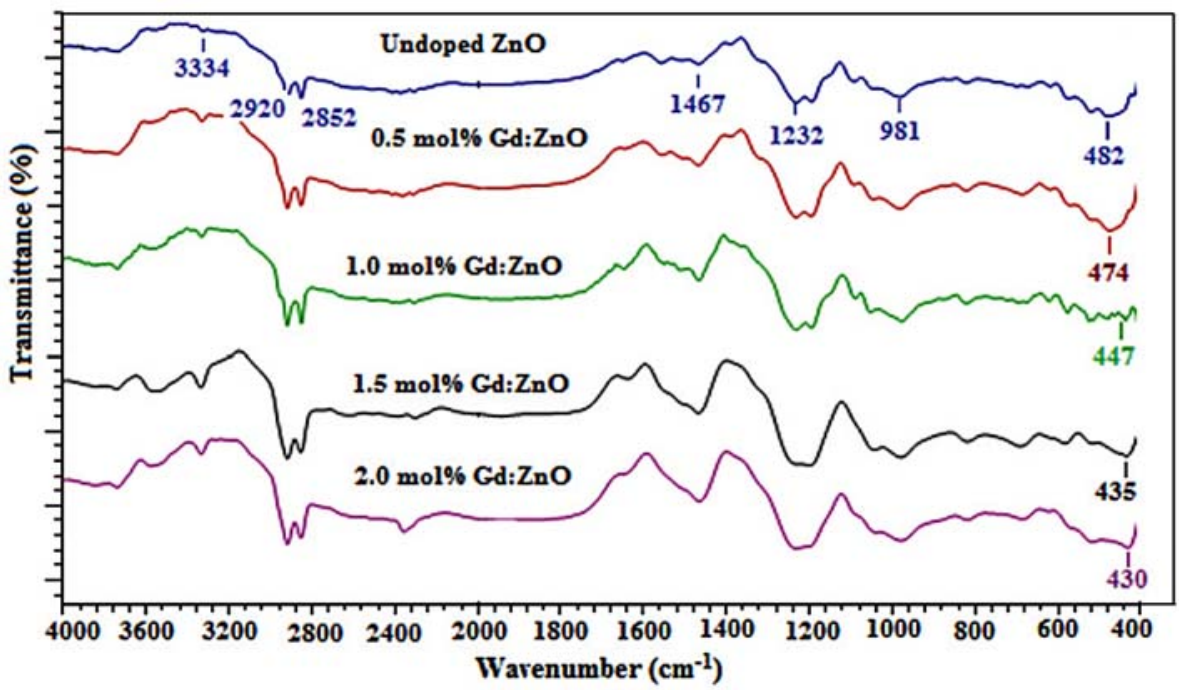

Figure 2a. FT-IR spectra of undoped and Gd doped $\mathrm{ZnO}$ nanoparticles synthesized using CTAB.

$4000-400 \mathrm{~cm}^{-1}$. Figures $2 \mathrm{a}$ and $2 \mathrm{~b}$ show the IR spectra of undoped and $\mathrm{Gd}$ doped $\mathrm{ZnO}$ nanoparticles prepared in presence of CTAB and PVP respectively.

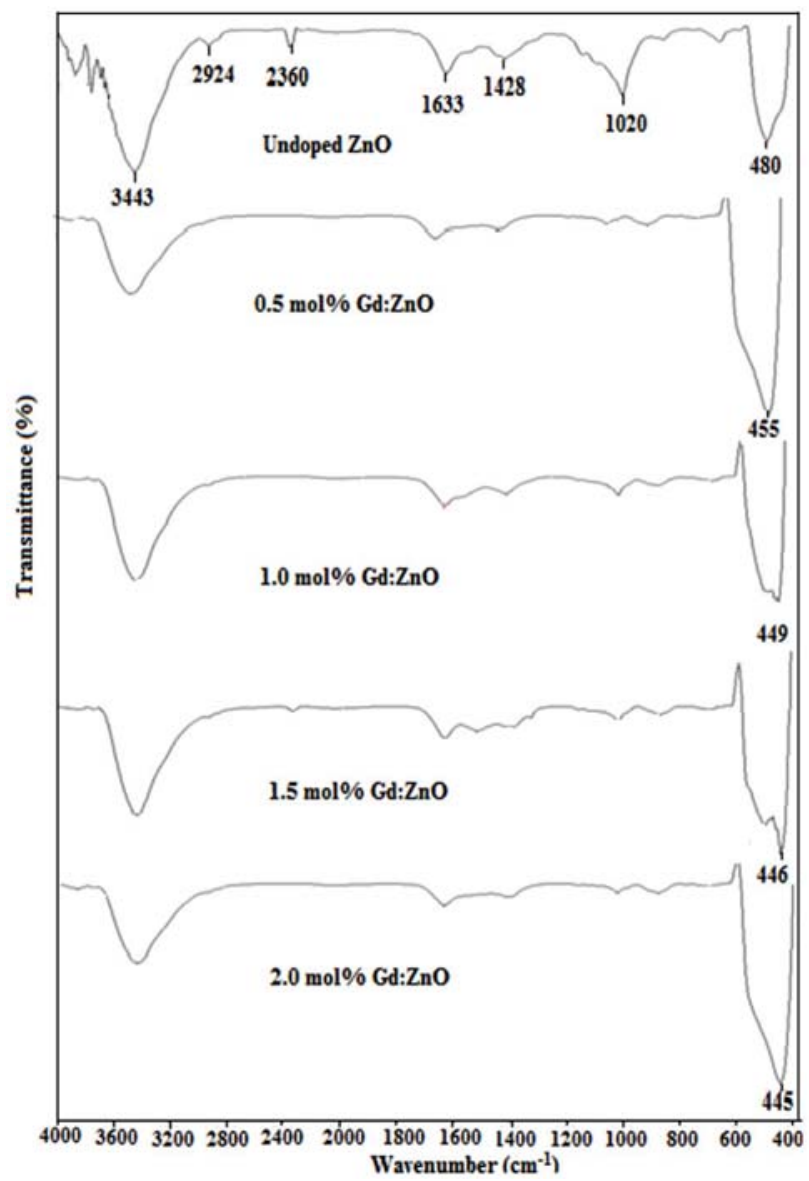

Figure 2b. FT-IR spectra of undoped and Gd doped $\mathrm{ZnO}$ nanoparticles synthesized using PVP.
The FT-IR spectra of samples show a prominent and characteristic absorption band in the range of 450-500 $\mathrm{cm}^{-1}$. This band is attributed to the stretching modes of $\mathrm{Zn}-\mathrm{O}$ bond. This characteristic absorption undergoes red shift on doping with $\mathrm{Gd}^{3+}$ (Table 1) which indicates that the $\mathrm{Zn}-\mathrm{O}-\mathrm{Zn}$ network is perturbed by the presence of $\mathrm{Gd}^{3+}$ in its environment. This means that $\mathrm{Zn}-\mathrm{O}$ bond strength decrease and/or bond length increases with increase in the concentration of dopant. A few absorption peaks were also observed between 900 and $2900 \mathrm{~cm}^{-1}$ in all samples. Absorption peaks around $980-1050 \mathrm{~cm}^{-1}$ is assigned to $\mathrm{C}-\mathrm{C}$ stretching mode of the acetate groups. The peaks around $1400-1600 \mathrm{~cm}^{-1}$ are attributed to the $\mathrm{C}-\mathrm{O}$ stretching modes (symmetric and asymmetric) and peaks around $2800-2900 \mathrm{~cm}^{-1}$ are attributed to $\mathrm{C}-\mathrm{H}$ bond of the acetate group. A broad band near $3400 \mathrm{~cm}^{-1}$ is assigned to stretching vibrations of the $\mathrm{O}-\mathrm{H}$ group of $\mathrm{H}_{2} \mathrm{O}$ molecules adsorbed on the surface of $\mathrm{ZnO}$ nanoparticles. The above result, therefore, suggest attachment of hydroxy $(-\mathrm{OH})$ and acetate $\left(\mathrm{CH}_{3} \mathrm{COO}\right)$ groups on the surface of undoped and $\mathrm{Gd}$ doped $\mathrm{ZnO}$ nanoparticles.

\section{2. Powder X-Ray Diffraction}

Figure $3(a, b)$ display XRPD patterns of the undoped and $\mathrm{Gd}$ doped $\mathrm{ZnO}$ nanoparticles prepared in CTAB and PVP medium respectively. In both cases, the diffraction peaks for samples doped with Gd corresponds to hexagonal wurtzite $\mathrm{ZnO}$ as reported in JCPDS card no. 36-1451, and no detectable diffraction peak for any impurity phase such as $\mathrm{Gd}_{2} \mathrm{O}_{3}, \mathrm{Gd}(\mathrm{OH})_{3}$, Gd metal or $\mathrm{Gd}-\mathrm{Zn}$ alloy was found. This indicated that the $\mathrm{Gd}^{3+}$ ions substituted $\mathrm{Zn}$ sites without changing the wurzite crystal structure of $\mathrm{ZnO}$ and without any precipitated phase or clustering. However, the diffraction peaks shift to lower angle slightly as dopant concentration (Gd) increases from 
0.5-2.0 mol\%, indicating that the lattice parameters get changed when $\mathrm{Gd}^{3+}$ are incorporated into $\mathrm{ZnO}$ lattice.

Table 2. Crystallite size of undoped and $\mathrm{Gd}$ doped $\mathrm{ZnO}$ calculated by Williamson-Hall method.

\begin{tabular}{lcc}
\hline Sample & $\begin{array}{c}\text { CTAB } \\
\boldsymbol{D} / \mathbf{n m}\end{array}$ & $\begin{array}{c}\text { PVP } \\
\boldsymbol{D} / \mathbf{n m}\end{array}$ \\
\hline Undoped $\mathrm{ZnO}$ & 56 & 52 \\
0.5 mol\% Gd: $\mathrm{ZnO}$ & 51 & 46 \\
1.0 mol\% Gd: $\mathrm{ZnO}$ & 46 & 41 \\
1.5 mol\% Gd: $\mathrm{ZnO}$ & 42 & 39 \\
2.0 mol\% Gd: $\mathrm{ZnO}$ & 40 & 33 \\
\hline
\end{tabular}

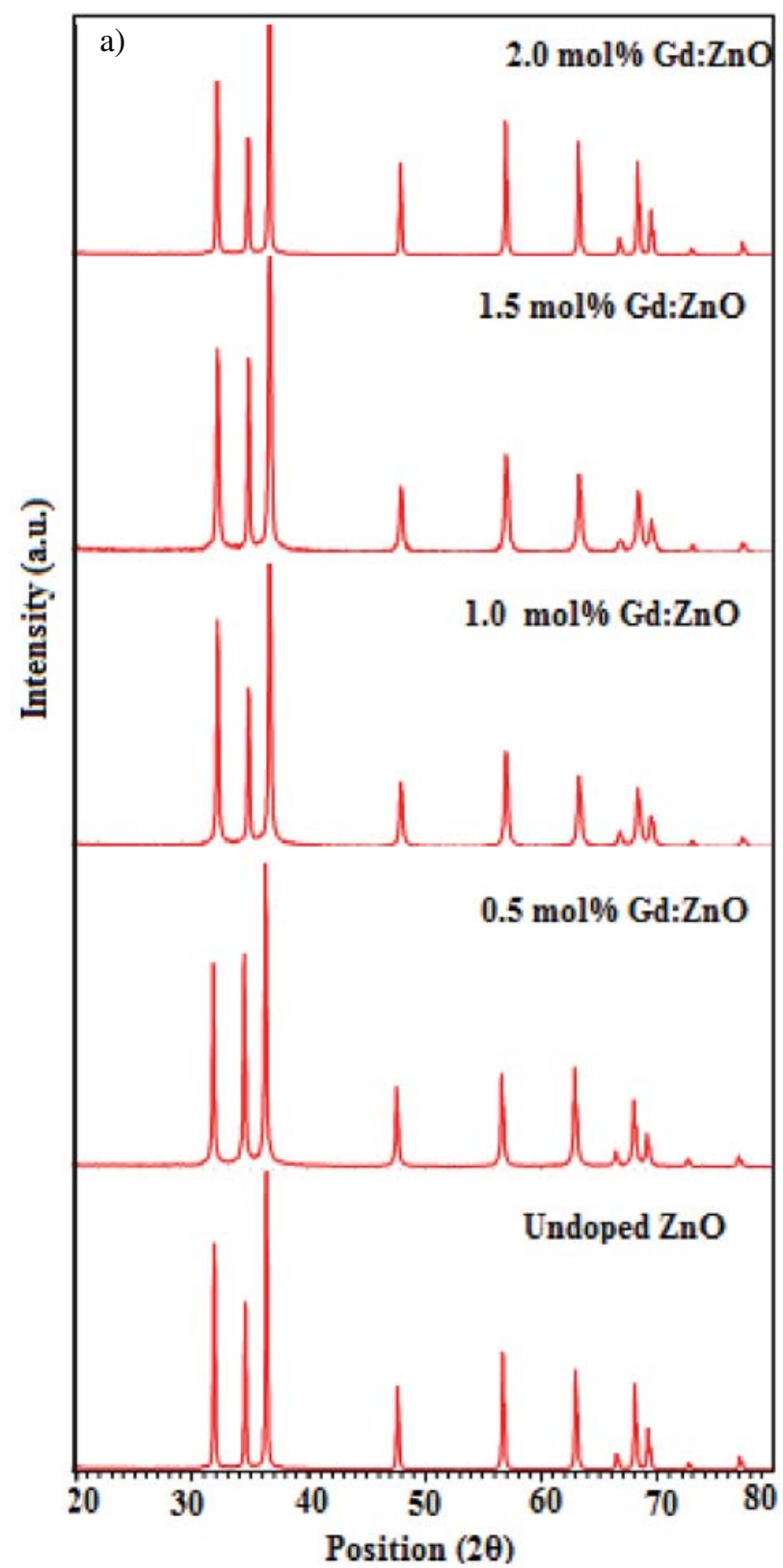

This is due to the reason that the ionic radius of $\mathrm{Gd}^{3+}(\mathrm{R}=$ $0.94 \AA$ ) is bigger than that of $\mathrm{Zn}^{2+}(\mathrm{R}=0.74 \AA)$.

It is noted that the full width at half maximum (FWHM) of the diffraction peaks of $\mathrm{ZnO}$ changes with change in concentration of dopant $\left(\mathrm{Gd}^{3+}\right)$ and nature of surfactants. ${ }^{35}$ This affect on the crystallite size of undoped and doped $\mathrm{ZnO}$ nanoparticles is estimated from XRD data by using Williamson-Hall method. ${ }^{36}$ The crystallite size of the doped $\mathrm{ZnO}$ nanoparticles is found to be smaller than undoped $\mathrm{ZnO}$ nanoparticles (Table 2). It may be due to the decrease in grain growth of $\mathrm{Gd}$ doped $\mathrm{ZnO}$ nanoparticles as compared to pure $\mathrm{ZnO}$ nanoparticles. The crystallite si$\mathrm{ze}$ of the nanoparticles is controlled by the rate of grain

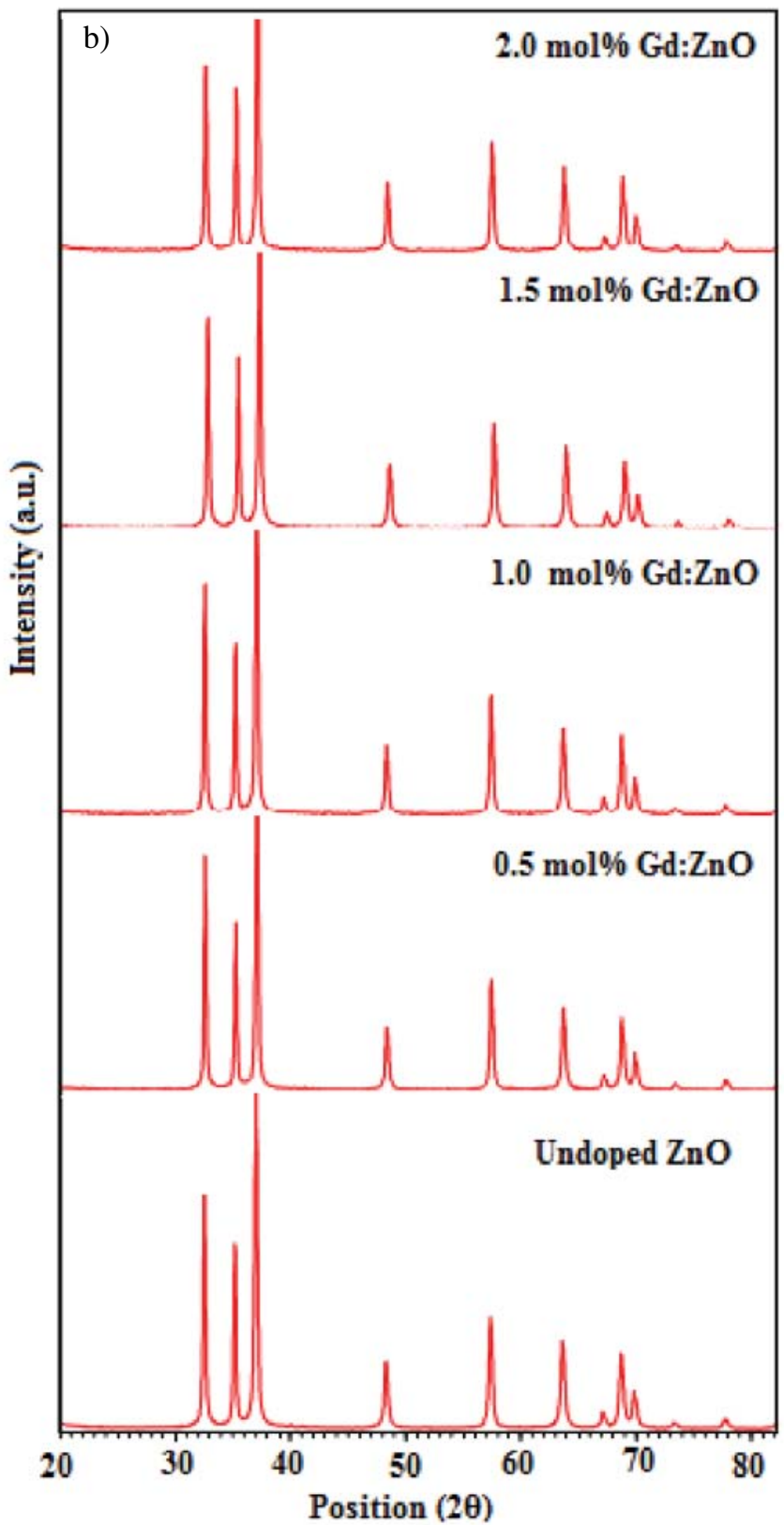

Figure 3. PXRD pattern of undoped and Gd doped $\mathrm{ZnO}$ nanoparticles synthesized using (a) CTAB and (b) PVP. 
growth which in turn depends upon movement of grain boundaries. The growth of the crystal grains can be prevented by resisting the motion of grain boundaries. Smaller crystallite sizes of doped nanoparticles suggest the presence of secondary phase or impurity (dopant) as a main reason for preventing the motion of grain boundaries and thus growth of doped $\mathrm{ZnO}$ nanoparticles. ${ }^{37}$
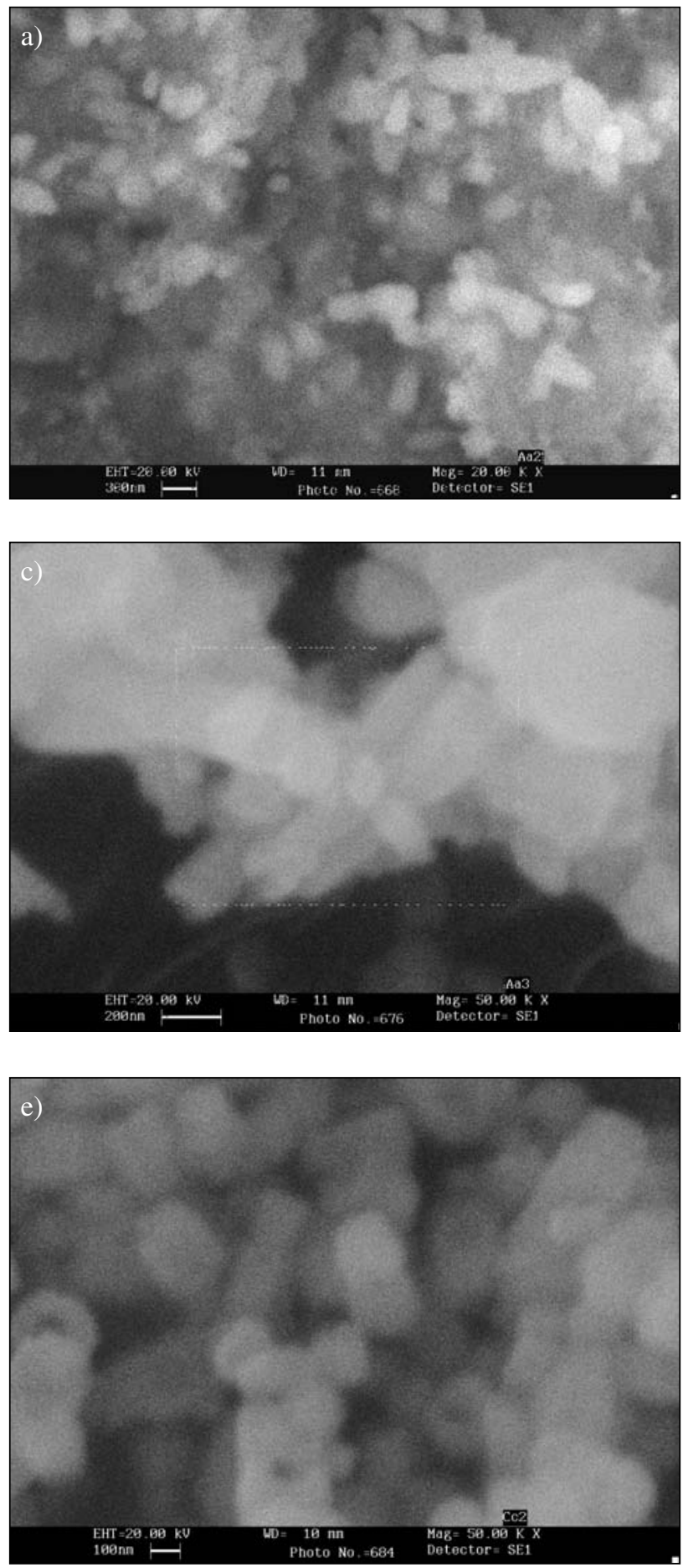

\section{3. Scanning Electron Microscopy}

The surface morphology of the $\mathrm{Gd}^{3+}$ doped $\mathrm{ZnO}$ nanoparticles (CTAB/PVP) was examined with scanning electron microscope. SEM micrographs of $\mathrm{Gd}^{3+}$ doped $\mathrm{ZnO}(\mathrm{CTAB})$ show nanorods and flowerlike nanostructures (Figure $4(\mathrm{a}-\mathrm{c})$. However, SEM micrographs of $\mathrm{Gd}^{3+}$
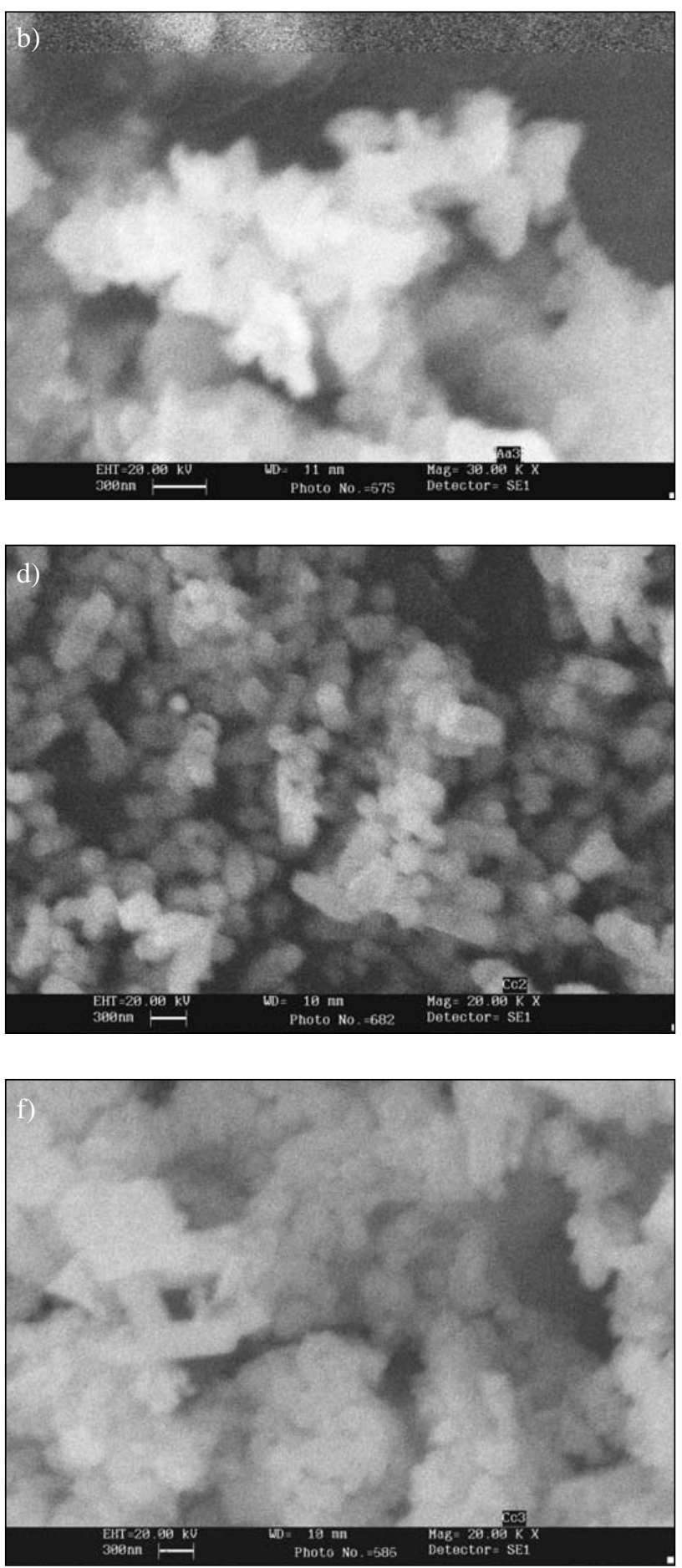

Figure 4. SEM micrographs of (a) $1.0 \mathrm{~mol} \% \mathrm{Gd}$ doped $\mathrm{ZnO}$ (CTAB) (b, c) $1.5 \mathrm{~mol} \% \mathrm{Gd}$ doped $\mathrm{ZnO}$ (CTAB) (d, e) $1.0 \mathrm{~mol} \% \mathrm{Gd}$ doped ZnO (PVP) (f) $1.5 \mathrm{~mol} \% \mathrm{Gd}$ doped $\mathrm{ZnO}$ (PVP). 
doped $\mathrm{ZnO}$ nanoparticles (PVP) show clusters of spherical shaped particles (Figure $4(\mathrm{~d}-\mathrm{f})$. The results suggest that surfactants can control the morphology of particles. The aggregation of the particles increases with increase in the dopant concentration.

\section{4. Energy Dispersive X-Ray Spectroscopy}

EDS was performed to investigate the presence and concentration of dopant in the doped $\mathrm{ZnO}$ nanoparticles. Figure 5(a-d) show energy dispersive X-ray spectra of $\mathrm{Gd}$ doped $\mathrm{ZnO}$ covered over width of $23 \mathrm{~nm}$. The results confirm that prepared $\mathrm{Gd}$ doped $\mathrm{ZnO}(\mathrm{CTAB} / \mathrm{PVP})$ nanoparticles are assuredly composed of $\mathrm{Gd}, \mathrm{Zn}$, and $\mathrm{O}$. Atomic ratios of $\mathrm{Zn}: \mathrm{O}: \mathrm{Gd}$ in 1.0 and $1.5 \mathrm{~mol} \% \mathrm{Gd}: \mathrm{ZnO}$ (CTAB/PVP) are given in Table 3. In general, lesser amount of Gd was found in the doped samples than provided in the precursor solution. This indicates that there are some hindrances during incorporation of the dopant into the host lattice. This may be because of the large difficulties associated with the doping of rare earth ions into the $\mathrm{ZnO}$ host. Firstly, the ionic radii of $\mathrm{RE}$ ions (e.g., $\mathrm{Gd}^{3+}=0.94 \AA$ ) are much larger than that of the $\mathrm{Zn}^{2+}$ ion $(0.74 \AA)$; and secondly, the substitution creates a charge imbalance, as $\mathrm{RE}^{3+}$ ions (charge: +3 ) substitute the $\mathrm{Zn}^{2+}$ sites (charge: +2 ) in the $\mathrm{ZnO}$ host matrix. Moreover, in the presence of different surfactants, the amount of dopant incorporated into the $\mathrm{ZnO}$ host is different for same concentration of doping. Higher amount of dopant is found in the $\mathrm{ZnO}$ lattice prepared in presence of PVP as compared to that of CTAB (Table 3). Thus, nature of surfactant has effect on the concentration of dopant incorporated in the host lattice. The elemental mapping of doped samples shows that $\mathrm{Gd}$ is uniformly distributed without any embedded nanoclusters (Figure 6).

Table 3. Weight and Atomic percentage of $\mathrm{Zn}, \mathrm{O}$, and Gd in Gd doped $\mathrm{ZnO}$ NPs calculated from EDS spectra.

\begin{tabular}{|c|c|c|c|c|c|c|c|c|}
\hline \multirow{3}{*}{ Elements } & \multicolumn{4}{|c|}{ CTAB } & \multicolumn{4}{|c|}{ PVP } \\
\hline & \multicolumn{2}{|c|}{$1.0 \mathrm{~mol} \%$ Gd: $\mathrm{ZnO}$} & \multicolumn{2}{|c|}{$1.5 \mathrm{~mol} \%$ Gd: $\mathrm{ZnO}$} & \multicolumn{2}{|c|}{$1.0 \mathrm{~mol} \%$ Gd: $\mathrm{ZnO}$} & \multicolumn{2}{|c|}{ 1.5mol\% Gd: $\mathrm{ZnO}$} \\
\hline & Wt. \% & At. $\%$ & Wt. \% & At. \% & Wt. \% & At. $\%$ & Wt. \% & At. $\%$ \\
\hline$\overline{\mathrm{Zn}}$ & 78.03 & 54.70 & 79.01 & 57.63 & 79.68 & 61.61 & 80.59 & 64.85 \\
\hline $\mathrm{O}$ & 15.11 & 43.30 & 13.44 & 40.08 & 11.22 & 35.47 & 9.70 & 31.90 \\
\hline Gd & 6.85 & 2.00 & 7.55 & 2.29 & 9.10 & 2.92 & 9.71 & 3.25 \\
\hline
\end{tabular}
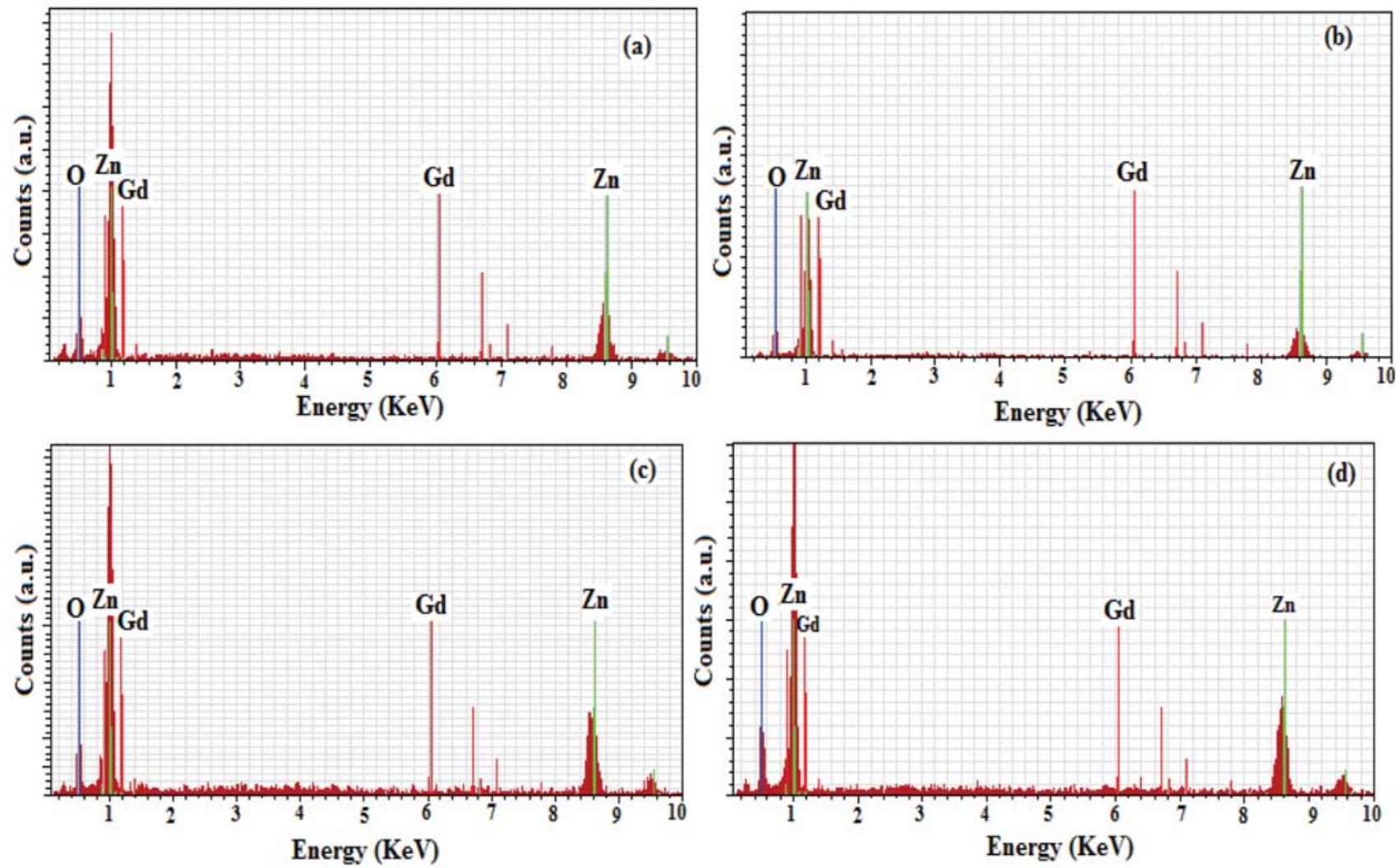

Figure 5. EDS spectra of (a) $1.0 \mathrm{~mol} \% \mathrm{Gd}$ doped $\mathrm{ZnO}$ (CTAB) (b) $1.5 \mathrm{~mol} \% \mathrm{Gd}$ doped $\mathrm{ZnO}$ (CTAB) (c) $1.0 \mathrm{~mol} \% \mathrm{Gd}$ doped ZnO (PVP) (d) 1.5 $\mathrm{mol} \% \mathrm{Gd}$ doped $\mathrm{ZnO}$ (PVP). 

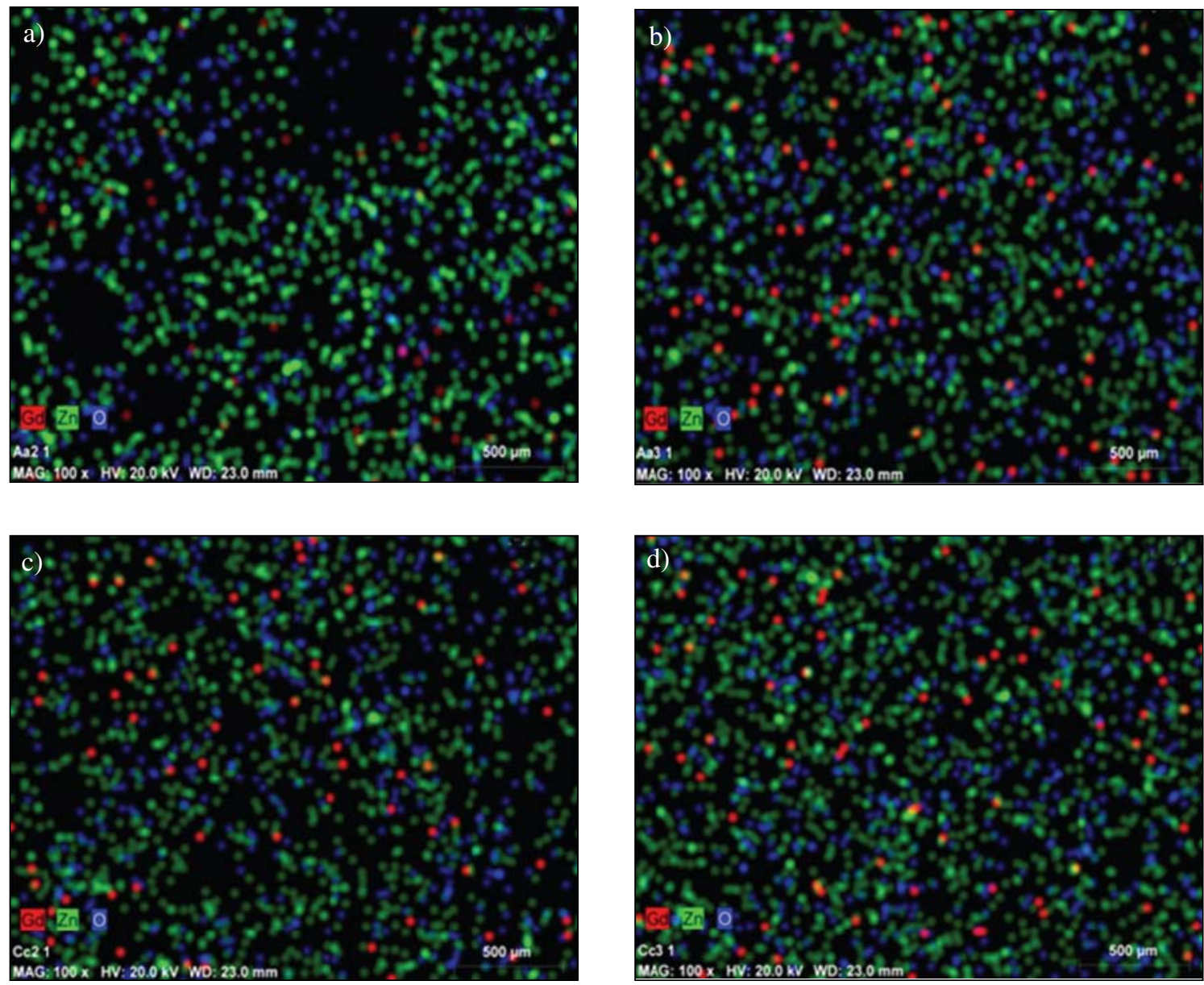

Figure 6. Elemental mapping of (a) $1.0 \mathrm{~mol} \% \mathrm{Gd}$ doped $\mathrm{ZnO}$ (CTAB) (b) $1.5 \mathrm{~mol} \% \mathrm{Gd}$ doped $\mathrm{ZnO}$ (CTAB) (c) $1.0 \mathrm{~mol} \% \mathrm{Gd}$ doped $\mathrm{ZnO}$ (PVP) (d) $1.5 \mathrm{~mol} \%$ Gd doped $\mathrm{ZnO}$ (PVP).

\section{5. Particle Size Analysis by Dynamic Light Scattering Technique}

The particle size distributions of the synthesized undoped and Gd doped $\mathrm{ZnO}$ nanoparticles (CTAB/PVP) we- re studied by dynamic light scattering technique. The average particle size distribution of synthesized undoped and doped $\mathrm{ZnO}$ is presented in Figure 7. The nanoparticles were uniformly dispersed in aqueous medium by mild sonication for $10 \mathrm{~min}$ before DLS analysis. The approximate size of
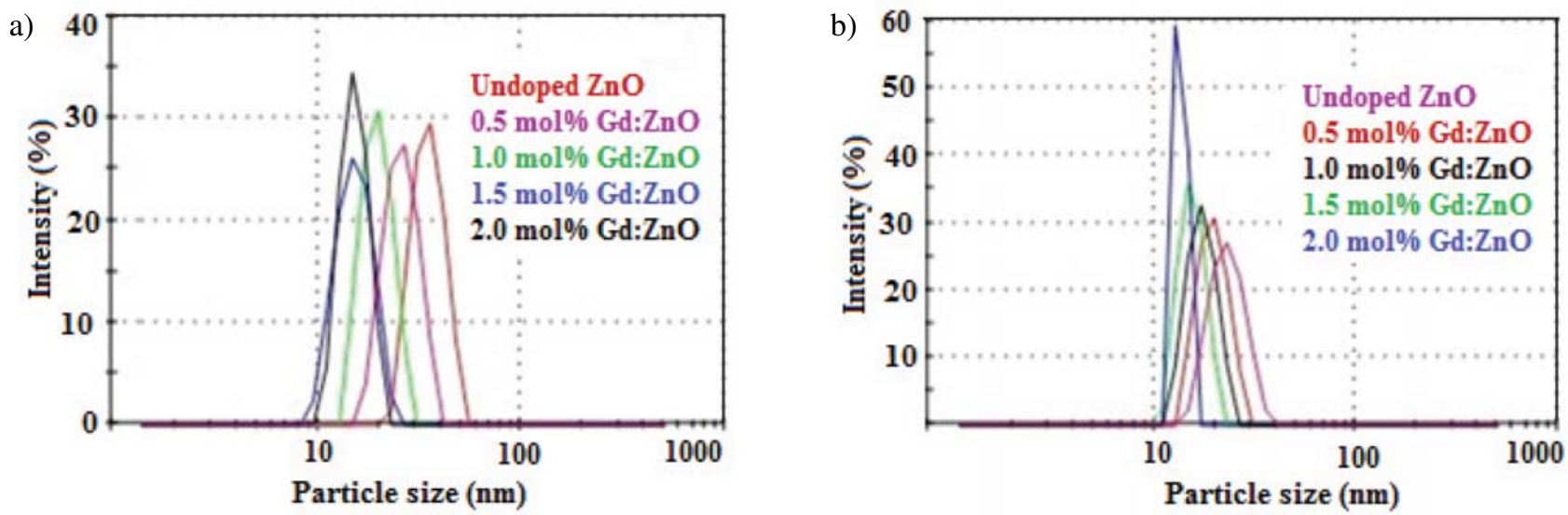

Figure 7. Particle size distribution of undoped and Gd doped $\mathrm{ZnO}$ nanoparticles synthesized using (a) CTAB and (b) PVP. 
undoped $\mathrm{ZnO}$ nanoparticles is found to be $50 \mathrm{~nm}$ and 38 $\mathrm{nm}$ for CTAB and PVP medium respectively. The particle size of doped nanoparticles decreases with increase in the concentration of dopant. The particle size of the product obtained in the presence of PVP is smaller than that in CTAB.

\section{6. UV-Visible Spectroscopy}

The optical property and band gap of surfactant (PVP /CTAB) assisted undoped and Gd doped nanoparticles were studied using absorption spectra. The UV-Vis spectra of undoped and doped $\mathrm{ZnO}$ samples are shown in Figure 8. The PVP and CTAB assisted undoped $\mathrm{ZnO}$ shows an absorption peak at $379 \mathrm{~nm}$ and $369 \mathrm{~nm}$ respectively, which undergoes red shift on doping with Gd. The absorption refers to the transition of electrons from the valence band to conduction band and band gap is the energy difference (in electron volts) between the top of the valence band and the bottom of the conduction band in semiconductors. The optical bandgap of the undoped and doped $\mathrm{ZnO}$ was calculated using equation:

Table 4. Absorption wavelength and calculated bandgap of undoped and Gd doped $\mathrm{ZnO}$.

\begin{tabular}{lcccc}
\hline \multirow{2}{*}{ Sample } & \multicolumn{2}{c}{ CTAB } & \multicolumn{2}{c}{ PVP } \\
& $\boldsymbol{\lambda}$ /nm & $\boldsymbol{E}_{\boldsymbol{g}} / \mathbf{e V}$ & $\boldsymbol{\lambda} \mathbf{\text { nm }}$ & $\boldsymbol{E}_{\boldsymbol{g}} \mathbf{e V}$ \\
\hline Undoped $\mathrm{ZnO}$ & 369 & 3.36 & 379 & 3.27 \\
0.5 mol\% Gd: $\mathrm{ZnO}$ & 372 & 3.33 & 380 & 3.26 \\
1.0 mol\% Gd: ZnO & 375 & 3.30 & 385 & 3.22 \\
1.5 mol\% Gd: ZnO & 381 & 3.25 & 386 & 3.21 \\
2.0 mol\% Gd: ZnO & 383 & 3.2 & 395 & 3.13 \\
\hline
\end{tabular}

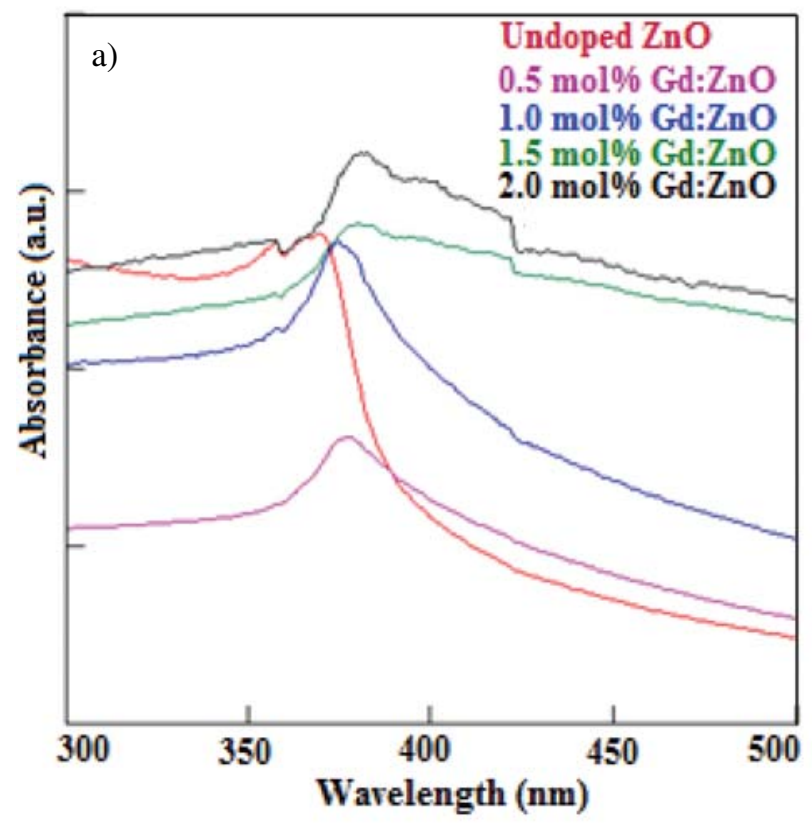

$$
E_{g}=\mathrm{hc} / \lambda=1240 / \lambda
$$

where $E_{g}$ is the bandgap in $\mathrm{eV}, \lambda$ is the wavelength in $\mathrm{nm}$.

The calculated band gaps for the Gd-doped $\mathrm{ZnO}$ samples are given in Table 4 and it is observed that band gap decreases with increase in the concentration of dopant which is due to the fact that dopant ions introduce new electronic levels inside the $\mathrm{ZnO}$ band gap.

\section{7. Effect of Nature of Surfactant on Doping}

Surfactants affect the stoichiometric composition and morphology of nanoparticles. A surfactant molecule has a hydrophilic head and a long hydrophobic tail. The overall mechanism of action of surfactant system is such that their molecules embrace the crystals and control their excess growth. CTAB is a cationic surfactant with positively charged head and a long hydrophobic tail. In CTAB solution, the zinc acetate molecules come closer to the positively charged micellar head region due to the electrostatic interactions between the head groups of cationic micelles and negatively charged acetate groups of zinc acetate which result in localization of the zinc acetate precursor on the micellar surface. Thus, the micellar surface becomes the preferred reaction site for the formation of the intermediate. However, positively charged CTAB head region may inhibit the approach of $\mathrm{Gd}^{3+}$ ions on the surface of $\mathrm{ZnO}$ intermediate due to electrostatic repulsion, thus less amount of dopant was inserted in the CTAB assisted doped $\mathrm{ZnO}$. In case of PVP, the polyvinyl backbone serves as a hydrophobic group whereas the pyrrolidone

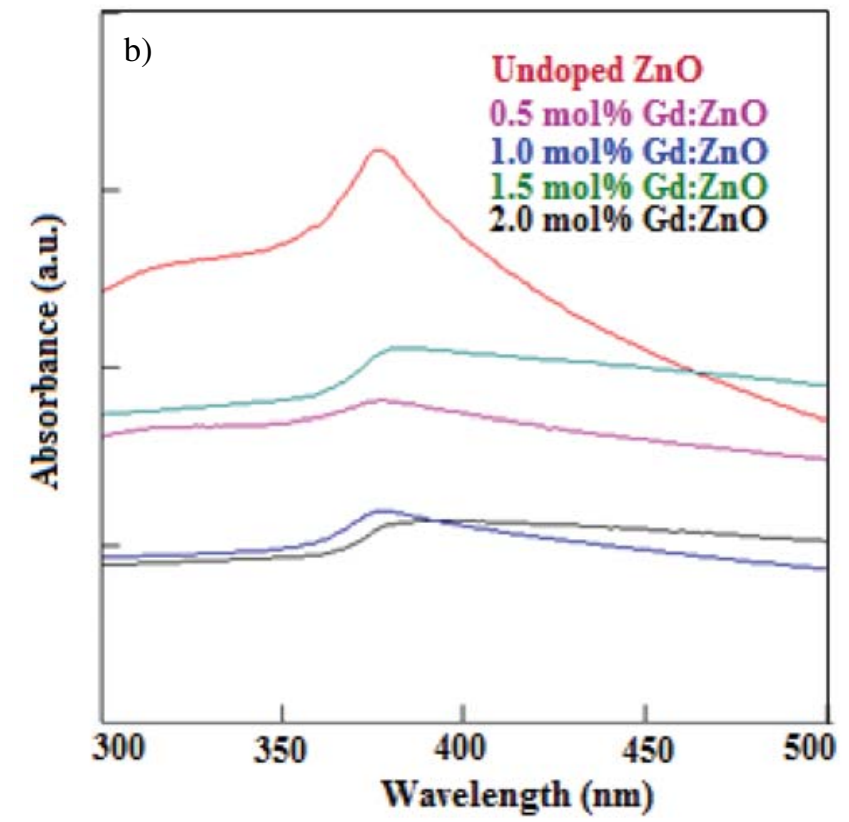

Figure 8. UV- Vis spectra of undoped and Gd doped $\mathrm{ZnO}$ nanoparticles synthesized using (a) CTAB and (b) PVP. 
group serves as a hydrophilic group. The carbonyl functional groups of PVP coordinate onto the $\mathrm{Zn}^{2+}$ ions of intermediate surfaces. A coordinative bonding of $\mathrm{CO}$ to $\mathrm{Zn}^{2+}$ at the $\mathrm{ZnO} / \mathrm{PVP}$ interface may form. $\mathrm{Gd}^{3+}$ ions also have coordinative interaction to CO of PVP so that they may be absorbed on the surface of intermediate through PVP. Thus, in this case comparatively high amount of dopant $(\mathrm{Gd})$ is incorporated into the host lattice.

\section{Conclusions}

Pure and Gd doped $\mathrm{ZnO}$ nanoparticles were prepared by sonochemical method in the presence of surfactants (PVP \& CTAB). XRPD studies confirmed the hexagonal wurtzite structure for all the samples. The presence of $\mathrm{Gd}$ ions within the $\mathrm{ZnO}$ lattice was confirmed by XRPD and FT-IR study. The microstructure analysis showed the different morphology for doped $\mathrm{ZnO}$ samples prepared in CTAB and PVP. The effect of nature of surfactants on doping was investigated by EDS studies which clearly showed that higher amount of dopant were inserted in the $\mathrm{ZnO}$ lattice in case of PVP than CTAB. UV-Visible spectroscopy indicated that the band gap for $\mathrm{Gd}$ doped $\mathrm{ZnO}$ nanoparticles decreases with an increase in Gd-doping as compared to pure $\mathrm{ZnO}$.

\section{References}

1. A. M. Smith, S. Nie, Acc. Chem. Res. 2010, 43, 190-200. http://dx.doi.org/10.1021/ar9001069

2. J. Liqiang, S. Xiaojun, S. Jing, C. Weimin, X. Zili, D. Yaoguo, F. Honggang, Sol. Energy Mater. Sol. Cells 2003, 79, 133-151. http://dx.doi.org/10.1016/S0927-0248(02)00393-8

3. H. Karami, M. Ghasemi, S. Matini, Int. J. Electrochem. Sci. 2013, 8, 11661-11679.

4. P. Rodriguez-Fragoso, J. Reyes-Esparza, A. Leon-Buitimea, L. Rodriguez-Fragoso, J. Nanobiotechnology 2012, 10, 1-11. http://dx.doi.org/10.1186/1477-3155-10-47

5. H. M. Chen, C. K. Chen, R. -S. Liu, L. Zhang, J. Zhang, D. P. Wilkinson, Chem. Soc. Rev. 2012, 41, 5654-5671. http://dx.doi.org/10.1039/c2cs35019j

6. J. Tian, Z. Zhao, A. Kumar, R. I. Boughton, H. Liu, Chem. Soc. Rev. 2014, 43, 6920-6937. http://dx.doi.org/10.1039/C4CS00180J

7. D. Sarkar, C. K. Ghosh, K. K. Chattopadhyay, Cryst. Eng. Comm. 2012, 14, 2683-2690.

http://dx.doi.org/10.1039/c2ce06392a

8. C. H. Chang, H. Jung, Y. Rheem, K. -H. Lee, D. -C. Lim, Y. Jeong, J. -H. Lim, N. V. Myung, Nanoscale 2013, 5, 16161623. http://dx.doi.org/10.1039/c2nr33029f

9. Y. Wang, Y. Yang, X. Zhang, X. Liu, A. Nakamurab, Cryst. Eng. Comm. 2012, 14, 240-245.

http://dx.doi.org/10.1039/C1CE05733B

10. N. Talebian, S. M. Amininezhad, M. Doudi, J. Photochem.
Photobiol. B 2013, 120, 66-73.

http://dx.doi.org/10.1016/j.jphotobiol.2013.01.004

11. Y. Yang, H. Lai, H. Xu, C. Tao, H. Yang, J. Nanopart. Res. 2010, 12, 217-225. http://dx.doi.org/10.1007/s11051-009-9598-x

12. S. H. Deng, M. Y. Duan, M. Xu, L. He, Physica B 2011, 406, 2314-2318. http://dx.doi.org/10.1016/j.physb.2011.03.067

13. J. Hays, K. M. Reddy, N. Y. Graces, M. H. Engelhard, V. Shutthanandan, M. Luo, C. Xu, N. C. Giles, C. Wang, S. Thevuthasan, A. Punnoose, J. Phys.: Condens. Matter 2007, $19,1-24$.

http://dx.doi.org/10.1088/0953-8984/19/26/266203

14. S. Harako, S. Yokoyama, K. Ide, X. Zhao, S. Komoro, Phys. Stat. Sol. (a) 2008, 205, 19-22.

http://dx.doi.org/10.1002/pssa.200776709

15 H. Chen, J. Ding, F. Shi, Y. Li, W. Guo, J. Alloys Compd. 2012, 534, 59-63. http://dx.doi.org/10.1016/j.jallcom.2012.04.064

16. R. Krishna, D. Haranath, S. P. Singh, H. Chander, A. C. Pandey, D. Kanjilal, J. Mater Sci. 2007, 42, 10047-10051. http://dx.doi.org/10.1007/s10853-007-2053-4

17. M. K. Lima, D. M. Fernandes, M. F. Silva, M. L. Baesso, A. M. Neto, G. R. Morais, C. V. Nakamura, A. O. Caleare, A. A. W. Hechenleitner, E. A. G. Pineda, J. Sol-Gel Sci. Technol 2014, 72, 301-309. http://dx.doi.org/10.1007/s10971-014-3310-z

18. P. Yu, J. Wang, H. -Y. Du, P. -J. Yao, Y. Hao, X. -G. Li, J. Nanomater 2013, 2013, 1-6.

19. A. Phuruangrat, O. Yayapao, T. Thongtem, S. Thongtem, $J$. Nanomater. 2014, 2014, 1-9.

20. J. H. Bang, K. S. Suslick, Adv. Mater. 2010, 22, 1039-1059. http://dx.doi.org/10.1002/adma.200904093

21. A. Khataee, A. Karimi, S. A. Oskoui, R. D. C. Soltani, Y. Hanifehpour, B. Soltani, S. W. Joo, Ultrason Sonochem. 2015, 22, 371-381. http://dx.doi.org/10.1016/j.ultsonch.2014.05.023

22. Hafeezullah, Z. H. Yamani, J. Iqbal, A. Qurashi, A. Hakeem, J. Alloys Compd. 2014, 616, 76-80. http://dx.doi.org/10.1016/j.jallcom.2014.07.015

23. H. Xu, B. W. Zeiger, K. S. Suslick, Chem. Soc. Rev. 2013, 42, 2555-2567. http://dx.doi.org/10.1039/C2CS35282F

24. X. Wu, Z. Wei, L. Zhang, X. Wang, H. Yang, J. Jiang, J. Nanomater. 2014, 2014, 1-6.

25. V. Gandhi, R. Ganesan, H. H. A. Syedahamed, M. Thaiyan, J. Phys. Chem. C 2014, 118, 9715-9725. http://dx.doi.org/10.1021/jp411848t

26. Y. Rao, H. Xu, Y. Liang, S. Hark, Cryst. Eng. Comm. 2011, 13, 2566-2570. http://dx.doi.org/10.1039/c0ce00730g

27. J. Geng, G.-H. Song, J. -J. Zhu, J. Nanomater. 2012, 2012, $1-5$.

28. B. Shahmoradi, K. Soga, S. Ananda, R. Somashekar, K. Byrappac, Nanoscale 2010, 2, 1160-1164. http://dx.doi.org/10.1039/c0nr00069h

29. S. Anandan, M. Miyauchi, Phys. Chem. Chem. Phys. 2011, 13, 14937-14945.

http://dx.doi.org/10.1039/c1cp21514k 
30. L. -W. Sun, H. -Q. Shi, W. -N. Li, H. -M. Xiao, S. -Y. Fu, X. -Z. Cao, Z. -X. Li, J. Mater. Chem. 2012, 22, 8221-8227. http://dx.doi.org/10.1039/c2jm00040g

31. Y. Liu, W. Luo, R. Li, G. Liu, M. R. Antonio, X. Chen, J. Phys. Chem. C 2008, 112, 686-694. http://dx.doi.org/10.1021/jp077001z

32. Y. Liu, K. Ai, Q. Yuan, L. Lu, Biomaterials 2011, 32, 11851192. http://dx.doi.org/10.1016/j.biomaterials.2010.10.022

33. J. Du, Z. Liu, Y. Huang, Y. Gao, B. Han, W. Li, G. Yang, J. Cryst. Growth 2005, 280, 126-134.

http://dx.doi.org/10.1016/j.jcrysgro.2005.03.006
34. T. Thilagavathi, D. Geetha, Appl. Nanosci. 2014, 4, 127132. http://dx.doi.org/10.1007/s13204-012-0183-8

35. R. S. Zeferino, M. B. Flores, U. Pal, J. Appl. Phys. 2011, 109, 014308(1-6).

36. A. K. Zak, W. H. A. Majid, M. E. Abrishami, R. Yousefi, Solid State Sci. 2011, 13, 251-256.

http://dx.doi.org/10.1016/j.solidstatesciences.2010.11.024

37. S. Singhal, J. Kaur, T. Namgyal, R. Sharma, Physica B 2012, 407, 1223-1226.

http://dx.doi.org/10.1016/j.physb.2012.01.103

\section{Povzetek}

S sonokemijsko metodo, pri kateri smo uporabili različne surfaktante (PVP/CTAB), smo sintetizirali ZnO in ZnO dopiran z Gd. Nanodelce smo karakterizirali s praškovno rentgensko difrakcijo (PXRD), infrardečo spektroskopijo (FTIR), vrstično elektronsko mikroskopijo (SEM), energijsko disperzivno rentgensko spektroskopijo (EDS) in UV-VIS spektroskopijo. Velikost delcev smo določili s tehniko dinamičnega sipanja svetlobe (DLS). Preučevali smo tudi vpliv Gd, kot dopirnega elementa in vpliv uporabljenega surfaktanta na velikost, morfologijo in optične lastnosti ZnO. Raziskovali smo tudi vpliv narave surfaktanta na množino Gd v mreži ZnO. 